\title{
Birokrasi Indonesia: Perspektif Teoritik dan Pengalaman Empirik
}

\author{
Suwarno \\ Universitas Muhammadiyah Purwokerto \\ E-mail: suwarn_ump@yahoo.com
}

In the era of reformation, leading to the establishment of a democratic civil society, it is necessary to reduce the role and power of bureaucracy that was previously predominant. The bureaucracy should be politically kept neutral, and strictly supervised by society alone, through for examples non governmental organizations, press, and their representatives elected through general election which is trustworthy and fair. Their lack of performance and their high pathology of corruption, collusion and nepotism should also be upgraded in order to be in conformity with a political life of Indonesia which is more democratic, open, and transparent, in line with the spirit of reformation.

Keywords: reformation, bureaucracy, reduce, upgraded

\section{Pendahuluan}

Era reformasi yang dimulai pada bulan -Mei 1998 membuat birokrasi menjadi lebih menarik untuk dibicarakan. Hal ini lantaran reformasi menuntut kehidupan politik yang terbuka, transparan, dan diterapkannya nilai-nilai pokok demokrasi seperti penghargaan terhadap hak asasi manusia (HAM), kebebasan, persamaan, keadilan, dan pertanggungjawaban. Sementara itu, birokrasi selama ini diindikasikan sebagai penghalang bagi tegaknya demokrasi karena lebih menjadi alat kekuasaan rezim daripada melayani rakyat secara memuaskan. Dengan demikian, dapat dikatakan menjadi dilema bagi demokrasi.

Persoalan mendasar birokrasi di Indonesia pada era reformasi sekarang ini ialah bagaimana membenahi birokrasi agar responsif, selaras, dan seirama dengan nilainilai pokok demokrasi yang kini telah menjadi wacana dan tuntutan publik. Apalagi dihadapkan pada pemberlakuan otonomi daerah sejak bulan Januari 2001 dengan diterapkannya UU No. 22/1999 mengenai pemerintah daerah dan UU No. 23/1999 tentang perimbangan keuangan pusat-daerah, birokrasi mutlak perlu dilakukan pembenahan.

Tulisan ini ingin mengelaborasi persoalan di atas. Tetapi sebelumnya akan dikaji mengenai birokrasi dari perspektif teoritik agar permasalahan menjadi lebih jelas. Selain itu, pengalaman empirik birokrasi di Indonesia secara historis juga akan memperkaya pemahaman tentang birokrasi, sekaligus menjadi patokan dalam membenahi birokrasi agar relevan dengan era reformasi yang menuntut kehidupan politik yang lebill demokratis.

\section{Kajian Pustaka}

\section{Arti, Fungsi, data Sumber Daya Politik Birokrasi}

Istilah birokrasi diadopsi secara langsung dari bahasa Inggris, dari kata bu- 
reaucracy. Secara etimologis, kata itu berasal dari akar kata bureau yang berarti meja tulis, yaitu tempat pejabat biasanya bekerja, ditambah kata cracy, yang bermakna aturan (nde). Tidak heran bila dalam kamus bahasa Eropa abad ke-18 dan ke-19, istilah birokrasi diartikan sebagai kekuasaan, pengaruh, atau wewenang yang dimiliki oleh para pejabat pemerintahan (Albrow, 1996).

Dewasa ini birokrasi kerap diartikan sebagai lembaga atau institusi yang melaksanakan fungsi-fungsi, dan tanggung jawab negara. Dengan kata lain, birokrasi merupakan kamar mesin (the engine-room) nya negara (Wright, ed., 1992). Birokrasi juga sering diartikan sebagai organisasi para pejabat yang tersusun secara hirarkis dan diangkat untuk melaksanakan tujuan-tujuan publik tertentu (Halevi, 1983).

Berbagai variasi anti birokrasi yang berkembang saat ini, sekurang-kurangnya -mengutip Albrow (1996)- dapat dirangkum menjadi tujuh pengertian, yaitu: (1) birokrasi sebagai organisasi yang rasional, (2) birokrasi sebagai lisensi organisasional, (3) birokrasi sebagai kekuasaan yang dijalankan oleh para pejabat, (4) birokrasi sebagai administrasi negara atau publik, (5) birokrasi sebagai administrasi yang dijalankan oleh para pejabat, (6) birokrasi sebagai bentuk organisasi yang memiliki ciri-ciri dan kualitas tertentu, dan (7) birokrasi sebagai salah satu ciri masyarakat modern.

Citra birokrasi yang ideal biasanya mengacu pada pemikiran Max Weber, sosiolog Jerman, dari para pendukungnya yang disebut sebagai Birokrasi Weberian (Weberian Bureaucracy). Birokrasi Weberian memiliki ciri utama, yaitu: (1) adanya derajat spesialisasi atau pembagian tugas yang jelas, (2) adanya struktur kewenangan hirarkhis dengan batas-batas tanggung jawab yang juga jelas, (3) hubungan antar anggota yang bersifat impersonal, (4) cara pengangkatan atau rekruitmen pagawai yang didasarkan pada kecakapan teknis, dan (5) adanya pemisahan antara urusan dinas dengan urusan pribadi yang akan menjamin pelaksanaan tugas secara efisien (Tjokrowinoto, 1995; Wright, 1992).

Mengenai fungsi birokrasi, ada tip kategori birokrasi yang melaksanakan fungsi berbeda. Pertama, birokrasi pemerintah umum, yakni institusi pemerintahan yang menjalankan tugas-tugas pemerintahan umum, termasuk tugas untuk memulihkan keamanan dan ketertiban dari tingkat pusat sampai ke daerah. Di sini birokrasi melaksanakan fungsi yang bersifat mengatur (regulative function). Kedua, birokrasi pembangunan, ialah institusi pemerintahan yang menyelenggarakan salah satu bidang khusus dalam rangka mencapai tujuan pembangunan, misalnya pendidikan, kesehatan, pertanian, industri, dan lain-lain. Dalam hal ini birokrasi menjalankan fungsi pembangunan (development function), atau fungsi adaptasi (adaptation,function). Ketiga, birokrasi pelayanan, yaitu unit-unit institusi yang berhubungan secara langsung dengan masyarakat, dengan memberikan jasa atau pelayanan. Termasuk dalam kategori birokrasi pelayanan, ialah sekolah-sekolah (dari tingkat SD hingga SMU), rumah sakit, kantor koperasi, bank rakyat, jawatan sosial, transmigrasi, dan lain sebagainya. Fungsi utama birokrasi kategori ketiga ini adalah fungsi pelayanan (service Action) (Abdullah dalam Millah Din Syamsuddin, peny., 1991).

Dalam pada itu, sumber daya politik atau kekuasaan yang dimiliki oleh birokrasi mencakup empat aspek yaitu: (1) aspek legal, (2) aspek material, (3) aspek strategis- 
UNISIA, Vol. XXXI No. 69 September 2008

operasional, dan (4) aspek tindakan politik. Aspek legal adalah berupa kontrol birokrasi atas implementasi kebijakan-kebijakan yang dibuat oleh para politisi. Aspek material, terutama berupa akses birokrasi kepada penggunaan anggaran belanja negara (national budget), peralatan seperti komputer, data, dan sumber daya manusia (SDM) yang handal. Aspek strategis-operasional ialah keunggulan birokrasi dalam hal keahlian, pengetahuan, spesialisasi, dan kontrol informasi, serta keputusan. Sedangkan aspek tindakan politik adalah kemampuan birokrasi dalam memanfaatkan semua sumber daya yang dimilikinya untuk melaksanakan kebijakan-kebijakan secara efisien ataupun untuk mengejar tujuan-tujuan mereka sendiri (Hill, ed.,1992).

Birokrasi mampu membangun jaringan kekuasaan yang lebih besar dan luas daripada yang dibuat oleh kekuatan nonbirokrasi, misalnya politisi, karena birokrasi mempunyai sumber daya politik atau kekuasaan yang relatif lebih besar dibanding kekuatan non-birokrasi. Kenyataan yang semacam ini adalah akibat dari ketidakmampuan politik kekuatan non-birokrasi dalam melakukan kontrol dan pengawasan terhadap birokrasi (Smith, 1988). Oleh karena itu, tidak mengherankan apabila di banyak negara berkembang atau Dunia Ketiga, terutama yang dikuasai oleh rezim otoritarian seperti halnya Indonesia di bawah Orde Baru, birokrasi memiliki peran yang sangat menentukan dalam kehidupan politik, khususnya dalam hal pengambilan keputusan (decision making).

\section{Birokrasi, Kapitalisme, dan Demokrasi}

Mengacu pada teori liberal tentang negara, birokrasi di satu pihak berada pada posisi yang bertentangan dengan kapitalisme dan demokrasi di lain pihak. Hal ini karena birokrasi, secara ekonomis, dianggap tidak sesuai dengan kapitalisme. Sementara itu secara politis, birokrasi sebagai pemerintah arif kekuasaan oleh para pejabat yang diangkat dipandang berada dalam posisi berlawanan dengan demokrasi sebagai pemerintahan, kekuasaan oleh rakyat melalui wakil-wakil mereka yang dipilih. Di sini birokrasi diposisikan sebagai merintangi laju pertumbuhan, kapitalisme maupun demokrasi yang saling mendukung satu sama lain. Hak-hak politik dan kebebasan yang melekat (inherent) dalam demokrasi diyakini berasal dari kebebasan ekonomi (kapitalisme). Sebaliknya, demokrasi hanya bisa tegak karena ditopang oleh kapitalisme, yang keduanya dihalangi oleh birokrasi (Smith, 1988).

Hubungan antara kapitalisme dengan demokrasi yang berjalin berkelindan memang dapat diamati dari sejarah lahirnya kapitalisme di Eropa Barat. Kapitalisme yang bertumpu pada sistem ekonomi pasar bukan hanya memerlukan inovasi yang ekonomis dalam proses pasar, melainkan juga memerlukan perubahan hukum dan politik yang menyeluruh. Perubahan hukum dan politik yang menyeluruh itu hanya terjadi apabila demokrasi ditegakkan, yakni kemerdekaan dan kebebasan perseorangan (individual) sebagai prasyarat bagi lancarnya sistem ekonomi pasar (Heilbroner, 1982). Momentum historisnya, antara lain: digulingkannya kekuasaan feodal monarkhiabsolut di Perancis dalam revolusi talum 1789 , dan naiknya kekuasaan parlemen serta revolusi industri di Inggris pada abad ke-18.

Birokrasi merupakan dilema bagi demokrasi karena hubungan di antara keduanya bersifat paradoks dan kontradiktif. Di satu pihak, kekuasaan birokrasi dapat menjadi ancaman bagi demokrasi. Di lain 
Birokrasi Indonesia Perspektif Teoritik dan...; Suwarno

pihak, demokrasi modern tidak akan dapat eksis tanpa birokrasi yang independen dan efisien. Ancaman birokrasi terhadap demokrasi dapat ditinjau dari tiga alasan. Pertama, birokrasi dapat menjadi alat untuk memperkuat dominasi negara yang lebih besar. Dalam beberapa kasus, birokrasi bahkan kerap tampil menjadi alat represi kekuasaan negara. Kedua, birokrasi berpotensi melanggar otonomi, kebebasan, dan privasi individual sebagai kekebalan yang merupakan esensi demokrasi. Ketiga, birokrasi berpotensi untuk mengontrol para politisi yang dipilih oleh rakyat dan mengambil alih bidang yang seharusnya ditangani oleh politisi (Halevy, 1983).

Bergulirnya arus globalisasi di dunia sejak akhir tahun 1980 an dan awal 1990an membawa serta nilai-nilai demokrasi dan kecenderungan diterapkannya pasar bebas (free - market) atau dalam bates tertentu kapitalisme. Demokrasi dan kapitalisme kemudian berkembang serta telah berubah menjadi tuntutan dan gejala universal untuk diterapkan oleh semua negara, tidak hanya negara-negara maju tetapi jugs negaranegara berkembang. Bahkan di negara komunis seperti Republik rakyat Cina (RRC) dan mantan komunis seperti Rusia dan negara-negara di kawasan Eropa Timur, telah mengadopsi, dalam batas-batas tertentu, kapitalisme dan demokrasi.

Berkenaan dengan itu, kekuasaan birokrasi yang terlalu kuat mencengkeram negara amat pantas dan mutlak perlu dikurangi untuk merespons kapitalisme dan demokrasi. Pengurangan kekuasaan birokrasi itu pada umuntnya dilakukan melalui kebijakan-kebijakan yang membatasi birokrasi, atau debirokratisasi. Di sinilah pentingnya proses demokratisasi sebagai altematif bagi birokrasi yang kelewat batas (Smith, 1988).

\section{Pengalaman Empirik Birokrasi di Indonesia}

Hampir di semua negara berkembang atau Dunia Ketiga dapat disaksikan munculnya peran dan kekuasaan birokrasi yang semakin besar. Ini ditandai oleh kekuasaan politik dan birokrasi yang terpusat pada sekelompok elit dan bersifat sentralistik. Kekuasaan birokrasi yang kuat dan besar di banyak negara berkembang pada satu sisi merupakan warisan kolonial, sementara pada lain sisi merupakan produk dari budaya feodal, terutama sistem hubungan patronage (patron-klien) dan privilege (hak-hak istimewa pada kelompok tertentu) (Wright, 1992).

Birokrasi di Indonesia, secara empirik juga mengikuti kecenderungan di atas. Ditinjau dari perspektif historis, birokrasi di Indonesia sudah terbentuk sejak masa kolonialisme Belanda. Bahkan jika ditelusuri lebih jauh barangkali telah ada pada masa kerajaan Majapahit ataupun kerajaan Mataram Islam. Namun birokrasi di Indonesia dalam pengertian modern sekarang memang sengaja diciptakan oleh pemerintah kolonial Belanda sejak abad ke$19 \mathrm{M}$ untuk menjadi alat kekuasaan dan represi pemerintah kolonial. Ketika itu birokrasi disebut dengan istilah "pangreh praja atau pamong praja". Rupanya pemerintah kolonial Belanda menyadari bahwa hubungan kekuasaan antara rakyat dengan penguasa pribumi (raja atau bupati) bersifat patron-klien (patronage). Rakyat mematuhi Para pembesar mereka yang dipandang dan dihormati karena dipercaya memiliki hak ketuhanan, yakni hak yang berasal dari Tuhan untuk mengurus rakyatnya. Pangreh praja atau pamong praja yang dibentuk oleh kekuasaan kolonial Belanda terdiri atas para bupati dan jabatanjabatan di bawahnya seperti wedana dan 
UNISIA, Vol. XXXI No. 69 September 2008

asisten wedana serta bawahan-bawahan mereka. Para pejabat tersebut mempunyai beberapa privilege (hak istimewa) tertentu yang tidak dimiliki oleh rakyat kebanyakan (Koesoemahatmadja, 1978).

Setelah Indonesia merdeka, peran dan kekuasaan birokrasi belum begitu menonjol hingga lahirnya pemerintahan rezim Orde Baru. Hal ini karena pada masa Revolusi Fisik (1945-1949), energi pemerintah dan rakyat habis digunakan untuk mempertahankan kemerdekaan yang diproklamasikan pada 17 Agustus 1945 dari rongrongan Belanda yang ingin menjajah kembali Indonesia.

Selama masa Demokrasi Liberal (19501958), kekuasaan dan pengaruh birokrasi belum begitu besar karena panggung kekuasaan politik didominasi oleh partaipartai yang berbeda aliran ideologi politiknya dan kerap timbul persaingan serta konflik di antara partai-partai tersebut. Selain itu, juga karena banyaknya pergolakan daerah di mana-mana seperti Gerakan DI/TII di Jawa Barat, Aceh, dan Sulawesi Selatan; serta PRRI di Sumatera Barat, dan Permesta di Sulawesi Utara.

Demikian pula pada masa Demokrasi Terpimpin (1959-1965). birokrasi relatif kurang berkembang peran dan kekuasaannya karena terlalu besarnya kekuasaan pribadi Presiden Soekarno. Di samping itu, juga karena adanya persaingan berebut pengaruh dan kekuasaan antara PKI dan TNI AD dalam mendekati Soekarno.

Birokrasi selama masa Orde Baru (1966-1998) menunjukkan perkembangan dalam peran dan kekuasaan yang semakin besar. Sejak awal tampaknya kepemimpinan rezim Orde Baru di bawah Jendral Soeharto meyakini, bahwa birokrasi dapat menjadi mesin yang efektif bagi pertumbuhan ekonomi negara yang sedang terpuruk saat itu. Kondisi ini hanya dapat dicapai jika birokrasi dijadikan sebagai struktur hirarkis tunggal yang komandonya tersentralisasi di bawah arahan politik rezim. Struktur birokrasi yang tersentralisasi dianggap sebagai prasyarat bagi stabilitas politik nasional dan kelangsungan proses pembangunan. Di dalam birokrasi kemudian diterapkan monoloyalitas politik hanya kepada rezim Orde baru) sebagai reaksi atas pengalaman periode sebelumnya, di mana birokrasi mengalami polarisasi secara sosiologis dan politis (Legowo, t.t.).

Perkembangan birokrasi yang semakin kuat dan mencengkeram negara dalam dekade pertama rezim Orde Baru ditempuh melalui tiga cara. Pertama, depolitisasi masyarakat, antara lain lewat jalur KORPRI di mana pegawai negeri wajib menjadi anggotanya. Kedua, stabilisasi keadaan. Instrumen yang dipakai, misalnya melalui pengangkatan perwira-perwira tinggi ABRI kini TNI pada jabatan-jabatan birokrasi yang strategis, termasuk menteri dan eselon I pada setiap departemen pemerintah. Ketiga, legitimasi kekuasaan, yaitu menjadikan GOLKAR sebagai organisasi politik (orpol) yang berfungsi sebagai alat untuk memobilisasi dukungan pada rezim (Legowo, t.t.).

Hingga akhir tahun 1980an, birokrasi berperan sangat efektif dalam menjalankan program-program administrasi dan ekonomi pemerintah. Dapat disebut contohnya sebagai berikut. Dalam sejumlah problem sosial dan ekonomi, birokrasi mampu merespons terhadap kegagalan pasar, mengantarkan program KB, mempromosikan teknik-teknik baru di bidang pertanian serta peningkatan varietas hasil panen. Di bidang politik, birokrasi tampil sukses menjadi mesin politik dalam memobilisasi dukungan kepada rezim. Pendeknya, birokrasi telah menjadi 
instrumen yang efektif bagi pemerintah rezim Orde baru dalam mengakselerasi pertumbuhan ekonomi, meningkatkan kesejahteraan sosial, dan mempertahankan stabilitas politik nasional (Legowo, t.t.).

Akan tetapi sejak awal tahun 1990an, birokrasi yang tadinya efektif berubah menjadi kurang efektif $\mathrm{Hal}$ ini barangkali karena pola kekuasaan birokrasi yang lebih dominan dari otoritarian dalam jangka waktu yang lama, justru akan menimbulkan resistensi dari masyarakat. Akibatnya akan mempersulit program-program pembangunan yang sebelumnya selalu dimotori oleh birokrasi (Pratikno, 1998).

Paling tidak ada dua alasan mengapa birokrasi rezin Orde baru pada dekade 1990an tidak algi efektif. Pertama, peluang pare birokrat yang sangat tinggi bagi terjadinya penyalahgunaan wewenang, terutama korupsi, kolusi dan nepotisme (KKN). Kedua, berkembangnya budaya di kalangan para birokrat yang hanya mau menang sendiri dan tidak menghargai pihak lain (Pratikno, 1998).

Sebenamya birokrasi di Indonesia selama Orde Baru secara teoritis dapat dikategorikan sebagai Birokrasi Weberian. Indikatornya antara lain terlihat pada struktur organisasi yang hirarkis dengan mekanisme yang terpusat atau sentralistik. Kemudian sistem karir yang bergantung pada prestasi, dedikasi, dan loyalitas individu birokrat. Namun dalam praktiknya, karena birokrasi digunakan sebagai mesin politik untuk memobilisasi dukungan kepada rezim Orde Baru, maka birokrasi tidak pernah netral dan justru memperalat atau diperalat (?) secara politis oleh Golkar. Dengan demikian, birokrasi di Indonesia selama Orde Baru agak jauh dari ideal Birokrasi Weberian. Mengutip Pratikno (1999: 2), birokrasi Indoesia selama Orde Baru dapat disebut sebagai birokrasi 'Weberian Setengah Hati'.
Hal ini karena birokrasi Indonesia tidak mampu dikontrol oleh politisi, dan justeru yang terjadi adalah sebaliknya, yaitu politisi yang dikontrol oleh birokrasi.

Dominasi birokrasi pada hampir seluruh arena percaturan politik sepanjang Orde Baru, terutama pada politisi, mengilhami para Indonesianis (pakar asing yang ahli Indonesia) dan ilmuwan Indonesia sendiri untuk membuat model kepolitikan Indonesia dengan fokus pada birokrasi. Sebagai contoh, model Bureaucratic Polity (Masyarakat Politik Birokratik) yang dibuat oleh Karl D. Jackson (1978), dan model Bureaucratic Authoritarianism (Otoritarianisme Birokratik) yang diajukan oleh Dwigh Y. King (1982). Sementara itu, Arief Budiman (1991) menyebut birokrasi Indonesia bermodel Birokratik Rente.

Model Bureaucratic Polity memusatkan perhatian pada pengambilan keputusan politik harus didukung oleh minimal adanya konsensus di kalangan elit militer dan birokrasi. Model Bureaucratic Authoritarianism menekankan pada pembuatan keputusan oleh rezim secara efektif, efisien, tidak bertele-tele, dan tidak memungkinkan adanya proses tawar-menawar yang lama. Dalam pada itu, model Birokratik Rente mensinyalir bahwa birokrasi cenderung dimanfaatkan oleh para birokrat bagi keuntungan ekonomi dan politik mereka sendiri.

\section{Pembahasan}

Penulis melihat ada dua aspek pokok birokrasi yang perlu dibenahi pada era reformasi agar selaras dengan proses demokratisasi yang ditengarai sedang berlangsung, dan terlebih kini telah memasuki masa pemberlakuan UU otonomi daerah. Dua aspek tersebut adalah : (I) kinerja birokrasi, dan (2) patologi birokrasi. Kinerja birokrasi Indonesia selama masa 
UNISIA, Vol. XXXI No. 69 September 2008

Orde Baru boleh dikatakan kurang baik dan optimal, sehingga berdampak pada timbulnya patologi birokrasi, terutama penyalahgunaan wewenang berupa tingginya angka korupsi, kolusi dan nepotisme (KKN)

Untuk memperbaiki kinerja birokrasi sekaligus mengurangi patologi birokrasi dapat ditempuh beberapa langkah sebagai berikut. Pertama, memperjelas model birokrasi Indonesia melalui perangkat hukum (misal: Undang-Undang atau Peraturan Pemerintah). Maksudnya, apakah birokrasi Indonesia akan mengacu pada model Eropa yang disebut Merit System, ataukah model Amerika Serikat (AS) yang dinamakan Spoil System. Model Eropa (Merit System) -yang mendasarkan pada ideal Birokrasi Weberianmenekankan netralitas birokrasi, sehingga birokrasi berada pada posisi yang netral dengan siapapun (politisi) partai yang sedang berkuasa. Di sini birokrasi mempersyaratkan pendidikan formal, pengalaman kerja, dan berorientasi pada karier dengan actian kepada prestasi, dedikasi, dan loyalitas kepada negara. Sebaliknya model AS (Spoil System) memahami birokrasi sebagai bagian dari pemerintah (partai) yang sedang berkuasa, sehingga setiap kali ada pergantian Presiden AS akan disusul oleh pergantian elit birokrasi.

Kedua, memperbaiki mentalitas para birokrat Indonesia yang citranya terlanjur buruk dan dituding sebagai salah satu faktor yang menyebabkan kinerja birokrasi Indonesia jelek serta terjadinya patologi birokrasi (KKN) Perbaikan mentalitas birokrat diarahkan agar mereka memilih etos kerja yang mengutamakan kerja keras, menghargai waktu, hemat, dan berdisiplin tinggi (Tjokrowinoto, 1995). Akan tetapi, hal ini harus dibarengi dengan pemberian kesejahteraan yang semakin baik kepada jajaran birokrasi.

Ketiga, meningkatkan kualitas kontrol kepada birokrasi. Selama ini birokrasi Indonesia relatif kurang mendapat kontrol dari masyarakat, atau melalui mekanisme kontrol masyarakat kepada birokrasi tidak berjalan optimal, meskipun ada WASKAT (Pengawasan melekat).

Mekanisme terhadap birokrasi, sebagai contoh, dapat dilihat pada tabel di bawah ini:

\begin{tabular}{|l|l|}
\hline \multicolumn{1}{|c|}{ FORMAL. } & \multicolumn{1}{c|}{ INFORMAL } \\
\hline Arahan politik oleh para mentri & \multicolumn{1}{c|}{ Eksternal } \\
Staf penasihat mentri & - Media massa \\
Penelitian cermat oleh legislatif & Opini publik \\
Penelitian cermat oleh lembaga & - Kelompok-kelompok kepentingan \\
pengadilan & Internal \\
Ombusemen & - Standar-standar profesional \\
\hline Keterlibatan warga negara & - Reaksi-reaksi antisipatif \\
(bilamana perlu secara legal) & Kelompok penekan sebaya \\
& Kesadaran \\
\hline
\end{tabular}

Sumber: Wright, Vincent (ed.). 1992. Comparative Government and politics An Introduction. London: The Macmillan Press Ltd., hlm. 354. 
Birokrasi Indonesia Perspektif Teoritik dan...; Suwarno

Keempat, memperbaiki hubungan antara pemerintah pusat dengan pemerintah daerah. Perbaikan hubungan pusat-daerah itu meliputi pemberian otonomi yang luas kepada daerah (terutama pada tingkatkabupaten-kotamadya), perimbangan pembagian keuangan pusatdaerah yang adil, dan diberlakukannya UU No 22/1999 tentang pemerintah daerah dan UU No 23/1999 tentang perimbangan keuangan pusat-daerah sejak 1 Januari 2001 ini, penulis kira akan dapat memperbaiki hubungan pusatdaerah yang selama Orde Baru kurang seimbang. Dalam hal ini, yang diperlukan adalah komitmen pemerintah pusat untuk melaksanakan kedua UU yang mengatur otonomi daerah tersebut secara serius dan tidak setengah-setengah.

\section{Penutup}

Dalam era refonnasi yang mengarah pada pembentukan 'Masyarakat Madani?' yang demokratis, birokrasi yang pada era sebelunmya terlalu dominan mutlak perlu untuk dikurangi peran dan kekuasaannya. Birokrasi harus dijaga netralitas politiknya dan diawasi secara ketat oleh masyarakat sendiri (misal, lewat LSM) atau melalui pers, wakilnya yang dipilih lewat pemilu yang jurdil (politisi yang berada di DPR). Sementara itu, kinerja. birokrasi yang sebelumnya kurang dengan patologi birokrasi yang tinggi (KKN) juga mutlak perlu dibenahi agar selaras dengan kehidupan politik Indonesia yang semakin demokratis, terbuka, dan transparan mengikuti semangat reformasi.

\section{Daftar Pustaka}

Abdullah, Syukri, 1991, "Budaya Birokrasi di Indonesia", dalam Allan dan Syamsuddin, Nazaruddin (paw.), Profil Budaya Politik Indonesia, Jakarta:Pustaka Utama Grafiti.
Albrow, Martin, 1996, Birokrasi, tcrjcmahan M. Rusli Karim dan Totok Daryanto, Yogyakarta:Tiara Wacana.

Halevy, Eva Etzioni, 1983, Bureaucracy and Democracy A Political Dilemma, London:Routledge Kegan Paul.

Heilbroner, Robert L., 1982, Terbentublya Masyarakat Ekoriorni, terjemahan Sutan Dianjung, Jakarta:Ghalia Indonesia.

Hill, Larry B. (ed)., 1992, The State of Public Bureaucracy, New York:M. E. Sharpe Inc.

Koesoemohatmadja, Djenal Hoesen, 1978, Perkembangan Fungsi dan Struktur Pamong Praja Ditinjau dari Segi Sejarah, Bandung:Alumni.

Legowo, T. A., t.t., "The Bureaucracy and Reform", dalam Baker, Richard W. (ed.), Indonesia The Challenge of Change,Netherland: KITLV.

Pratikno, 1998, "Urgensi Reformasi Basis Kekuasaan Birokrasi di Indonesia", dalam Arm' Kebijakan dan Administrasi Publik No. 1, Vol. 2,

Smith, B. C., 1988, Bureaucracy and Political Power, Wheatsheaf Books, Sussex.

Tjokrowinoto, Moeljarto, 1995, PollakPembangunan Sebuak Analisas, Arah, dan Strategi,Yogyakarta: Tiara wacana.

Wright, Vincent (ed.)., 1992, Comparative Government and Politics An Introduction, London:The Macmillan Press Ltd. 